Review

\title{
Graphene derivatives supported nanocatalysts for oxygen reduction reaction
}

\author{
Ilkeun Lee ${ }^{\mathrm{a}, *}$, Ji Bong Joo b,\#, Mohammadreza Shokouhimehr c,\$ \\ a Department of Chemistry, University of California, Riverside, CA, 92521, USA \\ b Low Carbon Process Lab, Korea Institute of Energy Research, Deajeon 305-343, Korea \\ c School of Chemical and Biological Engineering, College of Engineering, Seoul National University, Seoul 151-741, Korea
}

\section{A R T I C L E I N F O}

Article history:

Received 30 June 2015

Accepted 9 September 2015

Published 20 November 2015

\section{Keywords:}

Graphene

Oxygen reduction reaction

Electrocatalyst

Nanocatalyst

\begin{abstract}
A B S T R A C T
Very recent progress on the graphene derivatives supported variable nanocatalysts for oxygen reduction reaction (ORR) in fuel cell is reviewed. First, common electrochemical techniques to characterize graphene-based electrocatalysts are mentioned. Second, recent updates on graphene-derived electrocatalysts are introduced. In this part, both electrochemical activity and stability of Pt catalysts can be improved when they are supported by reduced graphene oxide (RGO). Other noble-metal catalysts including $\mathrm{Pd}, \mathrm{Au}$, and Ag showing comparable performance have been investigated. The stability of Pd catalyst is enhanced by RGO or few-layered graphene support. Synthetic approaches for $\mathrm{Au}$ or Ag catalysts supported on graphene oxide are discussed. In addition, non-noble transition metals in $\mathrm{N}_{4}$-chelate complexes can reduce oxygen electrochemically. $\mathrm{Fe}$ and Co are cheap alternative catalysts for ORR. In most cases, the stability and tolerance issues are overcome well, but their overall performances don't seem to surpass Pt/C catalyst yet.
\end{abstract}

(C) 2015, Dalian Institute of Chemical Physics, Chinese Academy of Sciences. Published by Elsevier B.V. All rights reserved.

\section{Introduction}

Graphene is a 2-D carbon material with one-atom thickness and excellent electrical conductivity, and has been one of the most talented materials in nanotechnology because of its unique chemical and physical properties. Very recently, graphene supported nanocatalysts have been highlighted by high surface area, electrical properties, and thermal stability [1].

We are now facing energy shortages and environmental pollution, and the huge demands for renewable and sustainable energy conversion technologies are emerging because fossil fuels will be depleted in near future [2]. The most important step in solving our energy and environmental concerns would be the development of a practical, safe, and efficient fuel cell.
For example, proton exchange membrane (PEM) fuel cell is a non-polluting ecological device and expected to be one of solutions [3]. Fuel cell converts chemical energy from a fuel to electricity through oxidation on anode and reduction on cathode. The most common fuel is $\mathrm{H}_{2}$, which can be produced from steam reforming of natural gas or water splitting. $\mathrm{H}_{2}$ is oxidized at anode to create a current, and hydrogen ions (protons) pass through an electrolyte membrane to cathode. $\mathrm{O}_{2}$ from air is reduced at cathode by the current, and then forms water. Unlike battery, electricity can be produced continuously as long as fuel is supplied [4].

Even though hydrogen fuel is a promising alternative to fossil fuel, the fuel cell still has some obstacles to be more affordable and popular: high costs and the stability of electrocatalysts.

\footnotetext{
* Corresponding author. E-mail: ilkeun@ucr.edu

* Corresponding author. E-mail: jbjoo@kier.re.kr

\$Corresponding author. E-mail: mrsh2@snu.ac.kr
}

DOI: 10.1016/S1872-2067(15)60971-8 | http://www.sciencedirect.com/science/journal/18722067 | Chin. J. Catal., Vol. 36 , No. 11, November 2015 
The splitting of hydrogen molecules is relatively easy when catalyzed by transition metals, but the kinetics of oxygen reduction is too slow to achieve the overall capability. Pt supported on carbon is widely used as a catalyst at both anode and cathode in spite of many drawbacks. Basically Pt is too expensive for commercialization in large-scale production. In addition, Pt suffers from serious issues including activity degradation, methanol crossover, and CO poisoning. Although many alternative catalysts have been investigated for oxygen reduction reaction (ORR), their electrocatalytic activity and stability are insufficient and low in most of cases. Among them, graphene is the best support for electrocatalysts because of large surface area and high conductivity, even though stacking of graphene sheets are prone to lower the surface active sites [1].

In this review, we summarize very recent major research progress on graphene derivatives supported transition metal nanoparticle-based catalysts (nanocatalysts) including their synthetic methods and electrocatalytic performance for ORR. We specifically highlight and discuss the strategies to utilize graphene derivatives as practicable supports for variable nanocatalysts with the investigated ORR electrocatalytic properties. We also explore their synthetic designs, characterizations, prospective applications, advantages, stabilities, durability and challenges of the introduced systems. This article is organized as follows: (1) common experimental techniques for electrocatalytic ORR, (2) graphene-derived electrocatalysts. Especially, we mainly deal with the details of graphene-derived electrocatalyst systems such as Pt-based electrocatalysts enhanced or optimized for ORR in fuel cell, the synthesis and preparation of non-Pt noble metal electrocatalysts, and selected examples of non-noble metal electrocatalysts.

\section{Experimental techniques in electrocatalytic ORR}

In PEM fuel cells, two electrochemical reactions take place at the surface of the two electrodes. Hydrogen oxidizes on anode, while oxygen reduces on cathode. The hydrogen oxidation reaction (HOR) has a lower overpotential and a higher kinetic rate than the ORR. Especially ORR is well known as slow due to high reduction overpotential, so the main focus in PEM fuel cell is related to speed up the ORR kinetics. The commonly used techniques to evaluate ORR performance are cyclic voltammetry, linear sweep voltammetry. polarization curves, Koutecky-Levich plot, and chronoamperometric response, etc [4]. Table 1 summarizes the experimental techniques in electrocatalytic ORR.

\subsection{Cyclic voltammetry}

Cyclic voltammetry is a very common technique in electrochemistry and shows the electrochemical response and catalytic activity of the catalysts for the reactions in a three-electrode electrochemical cell. ORR is measured mostly in an $\mathrm{O}_{2}$-saturated electrolyte solution in reversible potential range

Table 1

Summary of experimental conditions and techniques in electrocatalytic oxygen reduction reaction.

\begin{tabular}{|c|c|c|c|c|c|c|c|c|c|}
\hline Metal & $\begin{array}{c}\text { Graphene } \\
\text { type }\end{array}$ & $\begin{array}{c}\text { Dopant or } \\
\text { linker }\end{array}$ & Electrolyte & $\begin{array}{l}\text { Reference } \\
\text { electrode }\end{array}$ & Cyclic voltammetry & $\begin{array}{l}\text { RDE, Tafel } \\
\text { slope }\end{array}$ & $\begin{array}{c}\text { Durability } \\
\text { test }\end{array}$ & $\begin{array}{c}\text { Tolerance } \\
\text { test }\end{array}$ & Ref. \\
\hline$\overline{\mathrm{Pt}}$ & Graphene & $\begin{array}{l}\text { Perfluoro- } \\
\text { sulfonic acid }\end{array}$ & $0.5 \mathrm{~mol} / \mathrm{L} \mathrm{H}_{2} \mathrm{SO}_{4}$ & SCE & $0-1.2 \mathrm{~V}$ vs. RHE, $50 \mathrm{mV} / \mathrm{s}$ & $\mathrm{RDE}$ & 4000 cycles & $\mathrm{CO}$ & [12] \\
\hline $\mathrm{Pt}$ & RGO & - & $0.1 \mathrm{~mol} / \mathrm{L} \mathrm{HClO}_{4}$ & $\mathrm{Ag} / \mathrm{AgCl}$ & $0-1.1$ V vs. RHE, $100 \mathrm{mV} / \mathrm{s}$ & RDE & 20000 cycles & - & [13] \\
\hline $\mathrm{Pt}$ & RGO & - & $0.5 \mathrm{~mol} / \mathrm{L} \mathrm{H}_{2} \mathrm{SO}_{4}$ & SCE & $0-1.2 \mathrm{~V}$ vs. RHE, $50 \mathrm{mV} / \mathrm{s}$ & RDE & 4000 cycles & - & [14] \\
\hline $\mathrm{Pt}$ & RGO & Polydopamine & $0.1 \mathrm{~mol} / \mathrm{L} \mathrm{KOH}$ & $\mathrm{Ag} / \mathrm{AgCl}$ & $-0.8-0.4 \mathrm{~V}$ vs. $\mathrm{Ag} / \mathrm{AgCl}, 10 \mathrm{mV} / \mathrm{s}$ & RDE & $10000 \mathrm{~s}$ & - & [15] \\
\hline $\mathrm{Pt}$ & RGO & Nanodendrite & $0.1 \mathrm{~mol} / \mathrm{L} \mathrm{HClO}_{4}$ & $\mathrm{Ag} / \mathrm{AgCl}$ & $0-1.4 \mathrm{~V}$ vs. RHE, $50 \mathrm{mV} / \mathrm{s}$ & $\mathrm{RDE}$ & 10000 cycles & - & [55] \\
\hline $\mathrm{Pt}$ & Graphene & - & $0.5 \mathrm{~mol} / \mathrm{L} \mathrm{HClO}_{4}$ & SCE & $0-1.2 \mathrm{~V}$ vs. NHE, $20 \mathrm{mV} / \mathrm{s}$ & RDE & 1000 cycles & - & [56] \\
\hline $\mathrm{Pt}$ & Graphene & $\mathrm{TiO}_{2}$ & $\begin{array}{c}0.5 \mathrm{~mol} / \mathrm{L} \mathrm{H}_{2} \mathrm{SO}_{4} \\
0.1 \mathrm{~mol} / \mathrm{L} \mathrm{KOH}\end{array}$ & RHE & $0-1.4 \mathrm{~V}$ vs. RHE, $50 \mathrm{mV} / \mathrm{s}$ & RDE, Tafel & - & - & [57] \\
\hline $\mathrm{Pt}$ & Graphene & - & $0.5 \mathrm{~mol} / \mathrm{L} \mathrm{H}_{2} \mathrm{SO}_{4}$ & SCE & $0-1.2 \mathrm{~V}$ vs. RHE, $50 \mathrm{mV} / \mathrm{s}$ & RDE, Tafel & 500 cycles & Methanol & [58] \\
\hline $\mathrm{Pt}$ & RGO & - & $0.5 \mathrm{~mol} / \mathrm{L} \mathrm{HClO}_{4}$ & $\mathrm{Ag} / \mathrm{AgCl}$ & $0.1-1.1 \mathrm{~V}$ vs. $\mathrm{Ag} / \mathrm{AgCl}, 5 \mathrm{mV} / \mathrm{s}$ & $\mathrm{RDE}$ & - & - & [59] \\
\hline $\mathrm{Pt}$ & GO & - & $0.1 \mathrm{~mol} / \mathrm{L} \mathrm{HClO}_{4}$ & $\mathrm{Ag} / \mathrm{AgCl}$ & $0-1.4 \mathrm{~V}$ vs. RHE, $50 \mathrm{mV} / \mathrm{s}$ & RDE & 10000 cycles & - & {$[60]$} \\
\hline $\mathrm{Pt}$ & Graphene & $\begin{array}{l}\text { Perfluoro- } \\
\text { sulfonic acid }\end{array}$ & $0.5 \mathrm{~mol} / \mathrm{L} \mathrm{H}_{2} \mathrm{SO}_{4}$ & $\mathrm{Ag} / \mathrm{AgCl}$ & $0-1.2 \mathrm{~V}$ vs. NHE, $50 \mathrm{mV} / \mathrm{s}$ & $\mathrm{RDE}$ & 2000 cycles & - & [61] \\
\hline $\mathrm{Pt}$ & RGO & - & $0.1 \mathrm{~mol} / \mathrm{L} \mathrm{HClO}_{4}$ & $\mathrm{Ag} / \mathrm{AgCl}$ & $0-1.1 \mathrm{~V}$ vs. RHE, $100 \mathrm{mV} / \mathrm{s}$ & RDE & 20000 cycles & - & [62] \\
\hline Pd, Pt & Graphene & - & $0.1 \mathrm{~mol} / \mathrm{L} \mathrm{NaOH}$ & $\mathrm{Ag} / \mathrm{AgCl}$ & $0.2-1.2 \mathrm{~V}$ vs. RHE, $50 \mathrm{mV} / \mathrm{s}$ & $\mathrm{RDE}$ & - & - & [16] \\
\hline $\mathrm{Pd}, \mathrm{Pt}$ & RGO & - & $0.5 \mathrm{~mol} / \mathrm{L} \mathrm{H}_{2} \mathrm{SO}_{4}$ & $\mathrm{Hg} / \mathrm{Hg}_{2} \mathrm{SO}_{4}$ & $0-1$ V vs. NHE, $20 \mathrm{mV} / \mathrm{s}$ & RDE, Tafel & - & - & [63] \\
\hline $\mathrm{Pd}$ & RGO & - & $0.1 \mathrm{~mol} / \mathrm{L} \mathrm{KOH}$ & $\mathrm{Ag} / \mathrm{AgCl}$ & $0.1-1.2 \mathrm{~V}$ vs. RHE, $5 \mathrm{mV} / \mathrm{s}$ & RDE & 4000 cycles & - & [18] \\
\hline $\mathrm{Pd}$ & FLG & - & $0.1 \mathrm{~mol} / \mathrm{L} \mathrm{KOH}$ & $\mathrm{Hg} / \mathrm{HgO}$ & $0-1.2 \mathrm{~V}$ vs. RHE, $10 \mathrm{mV} / \mathrm{s}$ & RDE, Tafel & 2500 cycles & Methanol & [19] \\
\hline Pd & Graphene & - & $0.5 \mathrm{~mol} / \mathrm{L} \mathrm{H}_{2} \mathrm{SO}_{4}$ & $\mathrm{Ag} / \mathrm{AgCl}$ & $-0.2-1.1 \mathrm{~V}$ vs. $\mathrm{Ag} / \mathrm{AgCl}, 50 \mathrm{mV} / \mathrm{s}$ & - & - & - & [64] \\
\hline $\mathrm{Au}$ & RGO & - & $0.1 \mathrm{~mol} / \mathrm{L} \mathrm{KOH}$ & $\mathrm{Ag} / \mathrm{AgCl}$ & $-1-0.2$ V vs. RHE, $5 \mathrm{mV} / \mathrm{s}$ & $\mathrm{RDE}$ & 1000 cycles & Methanol & [28] \\
\hline $\mathrm{Au}$ & RGO & - & $0.1 \mathrm{~mol} / \mathrm{L} \mathrm{KOH}$ & SCE & $-0.8-0.2 \mathrm{~V}$ vs. $\mathrm{Hg} / \mathrm{Hg}_{2} \mathrm{Cl}_{2}, 5 \mathrm{mV} / \mathrm{s}$ & $\mathrm{RDE}$ & - & - & [31] \\
\hline $\mathrm{Au}$ & Graphene & $\mathrm{N}$ & $0.1 \mathrm{~mol} / \mathrm{L} \mathrm{KOH}$ & $\mathrm{Hg} / \mathrm{HgO}$ & $-0.8--0.5 \mathrm{~V}$ vs. $\mathrm{Hg} / \mathrm{HgO}, 10 \mathrm{mV} / \mathrm{s}$ & RDE, Tafel & - & - & [32] \\
\hline $\mathrm{Au}$ & RGO & - & $0.1 \mathrm{~mol} / \mathrm{L} \mathrm{KOH}$ & $\mathrm{Ag} / \mathrm{AgCl}$ & $-1.2-0.2 \mathrm{~V}$ vs. $\mathrm{Ag} / \mathrm{AgCl}, 50 \mathrm{mV} / \mathrm{s}$ & RDE & $4500 \mathrm{~s}$ & - & [33] \\
\hline $\mathrm{Au}$ & GO & S & $0.1 \mathrm{~mol} / \mathrm{L} \mathrm{KOH}$ & $\mathrm{Ag} / \mathrm{AgCl}$ & $-0.7-0.4 \mathrm{~V}$ vs. $\mathrm{Ag} / \mathrm{AgCl}, 50 \mathrm{mV} / \mathrm{s}$ & RDE, Tafel & $36000 \mathrm{~s}$ & - & [34] \\
\hline $\mathrm{Au}$ & Graphene & - & $0.1 \mathrm{~mol} / \mathrm{L} \mathrm{H}_{2} \mathrm{SO}_{4}$ & $\mathrm{Ag} / \mathrm{AgCl}$ & $-0.4-1.2 \mathrm{~V}$ vs. $\mathrm{Ag} / \mathrm{AgCl}, 20 \mathrm{mV} / \mathrm{s}$ & RDE & $50000 \mathrm{~s}$ & Methanol & [35] \\
\hline
\end{tabular}


Table 1 (Continued)

\begin{tabular}{|c|c|c|c|c|c|c|c|c|c|}
\hline Metal & $\begin{array}{l}\text { Graphene } \\
\text { type }\end{array}$ & $\begin{array}{l}\text { Dopant or } \\
\text { linker }\end{array}$ & Electrolyte & $\begin{array}{l}\text { Reference } \\
\text { electrode }\end{array}$ & Cyclic voltammetry & $\begin{array}{l}\text { RDE, Tafel } \\
\text { slope }\end{array}$ & $\begin{array}{c}\text { Durability } \\
\text { test }\end{array}$ & $\begin{array}{l}\text { Tolerance } \\
\text { test }\end{array}$ & Ref. \\
\hline$\overline{\mathrm{Au}}$ & GO & - & $0.1 \mathrm{~mol} / \mathrm{L} \mathrm{KOH}$ & SCE & $0.2-1.2 \mathrm{~V}$ vs. RHE, $10 \mathrm{mV} / \mathrm{s}$ & $\mathrm{RDE}$ & $5000 \mathrm{~s}$ & Methanol & {$[36]$} \\
\hline $\mathrm{Au}$ & RGO & - & $0.1 \mathrm{~mol} / \mathrm{L} \mathrm{KOH}$ & $\mathrm{Ag} / \mathrm{AgCl}$ & $-0.6-0.2 \mathrm{~V}$ vs. $\mathrm{Ag} / \mathrm{AgCl}, 50 \mathrm{mV} / \mathrm{s}$ & RDE & $7200 \mathrm{~s}$ & - & {$[37]$} \\
\hline $\mathrm{Au}$ & Graphene & - & $0.1 \mathrm{~mol} / \mathrm{L} \mathrm{KOH}$ & $\mathrm{Ag} / \mathrm{AgCl}$ & $-0.8-0.2 \mathrm{~V}$ vs. $\mathrm{Ag} / \mathrm{AgCl}, 50 \mathrm{mV} / \mathrm{s}$ & $\mathrm{RDE}$ & $72000 \mathrm{~s}$ & Methanol & [41] \\
\hline $\mathrm{Au}$ & RGO & - & $\begin{array}{l}0.1 \mathrm{~mol} / \mathrm{L} \\
\text { Phosphate }\end{array}$ & SCE & $-1.0-0$ V vs. SCE & - & $43200 \mathrm{~s}$ & $\begin{array}{l}\text { Water, Etha- } \\
\text { nol }\end{array}$ & [65] \\
\hline $\mathrm{Ag}$ & Graphene & $\mathrm{N}$ & $0.1 \mathrm{~mol} / \mathrm{L} \mathrm{KOH}$ & $\mathrm{Ag} / \mathrm{AgCl}$ & $-0.8-0.2 \mathrm{~V}$ vs. SHE, $10 \mathrm{mV} / \mathrm{s}$ & $\mathrm{RDE}$ & 8000 cycles & Methanol & [8] \\
\hline $\mathrm{Ag}$ & GO & - & $0.1 \mathrm{~mol} / \mathrm{L} \mathrm{NaOH}$ & $\mathrm{Hg} / \mathrm{HgO}$ & $0.1-1.5 \mathrm{~V}$ vs. RHE, $10 \mathrm{mV} / \mathrm{s}$ & RDE & - & Alcohols & {$[45]$} \\
\hline $\mathrm{Ag}$ & Graphene & Polyoxo-metalates & $0.1 \mathrm{~mol} / \mathrm{L} \mathrm{NaOH}$ & SCE & $-0.2-1.8 \mathrm{~V}$ vs. RHE, $50 \mathrm{mV} / \mathrm{s}$ & RDE & $20000 \mathrm{~s}$ & Methanol & [46] \\
\hline $\mathrm{Ag}$ & Graphene & - & $0.1 \mathrm{~mol} / \mathrm{L} \mathrm{KOH}$ & $\mathrm{Ag} / \mathrm{AgCl}$ & $-0.6-0.2 \mathrm{~V}$ vs. $\mathrm{Ag} / \mathrm{AgCl}$ & RDE & - & Methanol, CO & [47] \\
\hline $\mathrm{Ag}$ & RGO & - & $0.1 \mathrm{~mol} / \mathrm{L} \mathrm{K}_{2} \mathrm{SO}_{4}$ & $\mathrm{Hg} / \mathrm{HgO}$ & $-0.8-0.4 \mathrm{~V}$ vs. RHE, $10 \mathrm{mV} / \mathrm{s}$ & $\mathrm{RDE}$ & 30 cycles & - & [48] \\
\hline $\mathrm{Ag}$ & RGO & - & $0.1 \mathrm{~mol} / \mathrm{L} \mathrm{NaOH}$ & $\mathrm{Hg} / \mathrm{HgO}$ & $-0.9-0.25 \mathrm{~V}$ vs. $\mathrm{Hg} / \mathrm{HgO}, 5 \mathrm{mV} / \mathrm{s}$ & $\mathrm{RDE}$ & - & - & [49] \\
\hline $\mathrm{Ag}$ & Graphene & $\mathrm{N}$ & $1 \mathrm{~mol} / \mathrm{L} \mathrm{KOH}$ & $\mathrm{Ag} / \mathrm{AgCl}$ & $-0.7-0.5 \mathrm{~V}$ vs. $\mathrm{Ag} / \mathrm{AgCl}, 20 \mathrm{mV} / \mathrm{s}$ & - & - & - & [66] \\
\hline $\mathrm{Fe}$ & Graphene & Phthalocyanine & $0.1 \mathrm{~mol} / \mathrm{L} \mathrm{NaOH}$ & SCE & $-0.6-0.4 \mathrm{~V}$ vs. SCE, $50 \mathrm{mV} / \mathrm{s}$ & $\mathrm{RDE}$ & $10000 \mathrm{~s}$ & Methanol & [5] \\
\hline $\mathrm{Fe}$ & Graphene & $\mathrm{N}$ & $0.1 \mathrm{~mol} / \mathrm{L} \mathrm{HClO}_{4}$ & $\mathrm{Ag} / \mathrm{AgCl}$ & $0.2-1.2$ vs. RHE, $10 \mathrm{mV} / \mathrm{s}$ & RDE, Tafel & 30000 cycles & - & [6] \\
\hline $\mathrm{Fe}$ & RGO & $\mathrm{N}$ & $0.5 \mathrm{~mol} / \mathrm{L} \mathrm{H}_{2} \mathrm{SO}_{4}$ & $\mathrm{Ag} / \mathrm{AgCl}$ & $0-1.0 \mathrm{~V}$ vs. RHE, $10 \mathrm{mV} / \mathrm{s}$ & $\mathrm{RDE}$ & 1000 cycles & - & [7] \\
\hline $\mathrm{Fe}$ & Graphene & Phthalocyanine & $0.1 \mathrm{~mol} / \mathrm{L} \mathrm{KOH}$ & $\mathrm{Ag} / \mathrm{AgCl}$ & $0.2-1.4 \mathrm{~V}$ vs. $\mathrm{RHE}, 10 \mathrm{mV} / \mathrm{s}$ & $\mathrm{RDE}$ & $10000 \mathrm{~s}$ & Methanol, CO & {$[54]$} \\
\hline $\mathrm{Fe}$ & $\begin{array}{l}\text { Graphene } \\
\text { Aerogel }\end{array}$ & $\mathrm{N}$, Phthalocyanine & $0.1 \mathrm{~mol} / \mathrm{L} \mathrm{KOH}$ & $\mathrm{Ag} / \mathrm{AgCl}$ & $-1.2-0.2 \mathrm{~V}$ vs. $\mathrm{Ag} / \mathrm{AgCl}, 100 \mathrm{mV} / \mathrm{s}$ & RDE, Tafel & $20000 \mathrm{~s}$ & Methanol & [67] \\
\hline $\mathrm{Fe}$ & Graphene & $\begin{array}{c}\text { Tetrasulfo- } \\
\text { phthalocyanine }\end{array}$ & $0.1 \mathrm{~mol} / \mathrm{L} \mathrm{KOH}$ & $\mathrm{Ag} / \mathrm{AgCl}$ & $-1-0.2$ V vs. $\mathrm{Ag} / \mathrm{AgCl}, 100 \mathrm{mV} / \mathrm{s}$ & $\mathrm{RDE}$ & 10000 cycles & Methanol, CO & [68] \\
\hline $\mathrm{Fe}$ & Graphene & $\mathrm{N}$ & $0.1 \mathrm{~mol} / \mathrm{L} \mathrm{KOH}$ & RHE & $0.05-1.1 \mathrm{~V}$ vs. RHE, $5 \mathrm{mV} / \mathrm{s}$ & RDE, Tafel & $25000 \mathrm{~s}$ & Methanol, CO & [69] \\
\hline $\mathrm{Fe}$ & Graphene & $\begin{array}{l}\text { Polyphthalo- } \\
\text { cyanine }\end{array}$ & $0.1 \mathrm{~mol} / \mathrm{L} \mathrm{KOH}$ & SCE & $-0.7-0.2 \mathrm{~V}$ vs. SCE, $100 \mathrm{mV} / \mathrm{s}$ & $\mathrm{RDE}$ & $10000 \mathrm{~s}$ & Methanol & [70] \\
\hline $\mathrm{Fe}$ & RGO & Phthalocyanine & $0.1 \mathrm{~mol} / \mathrm{L} \mathrm{KOH}$ & $\mathrm{Ag} / \mathrm{AgCl}$ & $0.3-1.3 \mathrm{~V}$ vs. RHE, $50 \mathrm{mV} / \mathrm{s}$ & RDE, Tafel & $20000 \mathrm{~s}$ & Methanol & [71] \\
\hline $\mathrm{Fe}$ & RGO & - & $\begin{array}{c}10 \mathrm{mmol} / \mathrm{L} \\
\text { Ascorbic acid }\end{array}$ & $\mathrm{Ag} / \mathrm{AgCl}$ & $-0.2-1 \mathrm{~V}$ vs. $\mathrm{Ag} / \mathrm{AgCl}, 100 \mathrm{mV} / \mathrm{s}$ & - & - & - & {$[72]$} \\
\hline $\mathrm{Fe}$ & RGO & Phthalocyanine & $0.1 \mathrm{~mol} / \mathrm{L} \mathrm{KOH}$ & $\mathrm{Ag} / \mathrm{AgCl}$ & $0.4-1.2 \mathrm{~V}$ vs. RHE, $5 \mathrm{mV} / \mathrm{s}$ & RDE, Tafel & $25000 \mathrm{~s}$ & - & [73] \\
\hline $\mathrm{Fe}$, Co & Graphene & $\mathrm{N}$ & $0.1 \mathrm{~mol} / \mathrm{L} \mathrm{KOH}$ & SCE & $-1.2-0.2 \mathrm{~V}$ vs. SCE, $100 \mathrm{mV} / \mathrm{s}$ & & $150000 \mathrm{~s}$ & - & [9] \\
\hline Co & RGO & $\mathrm{N}$ & $0.1 \mathrm{~mol} / \mathrm{L} \mathrm{KOH}$ & $\mathrm{Ag} / \mathrm{AgCl}$ & $-1.0-0.2 \mathrm{~V}$ vs. $\mathrm{Ag} / \mathrm{AgCl}, 50 \mathrm{mV} / \mathrm{s}$ & $\mathrm{RDE}$ & $20000 s$ & Methanol & [74] \\
\hline Co & RGO & $\mathrm{N}$ & $0.1 \mathrm{~mol} / \mathrm{L} \mathrm{KOH}$ & SCE & $0-1.2 \mathrm{~V}$ vs. RHE, $10 \mathrm{mV} / \mathrm{s}$ & $\mathrm{RDE}$ & 10000 cycles & Methanol, CO & [75] \\
\hline
\end{tabular}

with a scan rate up to $100 \mathrm{mV} / \mathrm{s}$. Different concentrations or solutions such as $\mathrm{KOH}, \mathrm{NaOH}$ [5], $\mathrm{HClO}_{4}$ [6], or $\mathrm{H}_{2} \mathrm{SO}_{4}$ [7] can be used as electrolyte media. Pt wire and $\mathrm{Ag} / \mathrm{AgCl}$ are counter and reference electrodes, respectively. The current measured at the working electrode is plotted as a function of voltage. The activation energy barrier of an electrochemical reaction determines the reaction rate, which is described in current. So, current density is related to the charge transfer, reactant consumption, and the surface area. This current density is a net current density and easy to measure.

\subsection{Low overpotential}

Overpotential is the difference between the activation energy and the equilibrium potential. Exchange current density is the electrochemical reaction rate at equilibrium, and determines how rapidly the reaction can occur. A slow reaction means a larger overpotential for a given current density. In order to obtain high current at low overpotential, the exchange current density should be large. Low overpotential is highly desired as $\mathrm{O}_{2}$ reduction occurs at potentials as close as possible to the thermodynamic electrode potential via 4-electron process. If the exchange current density is large enough, high current can be measured at a low overpotential.
Tafel equation [4] is as follows:

$$
\eta=\left(\frac{2.303 R T}{a n F}\right) \ln \left(\frac{I_{\mathrm{C}}}{I_{\mathrm{E}}}\right)
$$

where $\eta$ is the overpotential of ORR, $R$ is the gas constant, $T$ is the temperature, $a$ is the transfer coefficient, $n$ is the number of electrons transferred, $I_{\mathrm{C}}$ is the current density, and $I_{\mathrm{E}}$ is the exchange current density. The lower the Tafel slope, the lower the overpotential.

\subsection{Rotating disk electrode}

Rotating disk electrode (RDE) is a hydrodynamic working electrode and rotates during the measurement of linear sweep voltammetry. RDE results are current-potential curves with different rotating rates. From the Koutecky-Levich equation, the Levich current density [4] can be expressed as follows:

$$
I_{\text {lev }}=0.201 n F A C_{02} D_{02}{ }^{2 / 3} v^{1 / 6} \omega^{1 / 2}
$$

where $n$ is the overall electron transfer number, $F$ is the Faraday constant, $A$ is the area of electrode, $C_{02}$ is the $\mathrm{O}_{2}$ concentraiton, $D_{02}$ is the diffusion coefficient of $\mathrm{O}_{2}, v$ is the kinematic viscosity of the electrolyte solution, and $\omega$ is the rotation rate. The slope of Koutecky-Levich plot $\left(I_{\mathrm{lim}^{-1}}\right.$ vs. $\left.\omega^{-1 / 2}\right)$ using RDE data indicates the number of electron transfer.

ORR occurs mainly by two general processes in aqueous 
solution; the desired route is water production via 4-electron pathway, and the other is hydrogen peroxide production via 2-electron pathway. In alkaline solution, 1-electron pathway to produce superoxide can also occur. If oxygen reduction isn't completed, $\mathrm{H}_{2} \mathrm{O}_{2}$ cause low efficiency in energy conversion.

\subsection{Durability test}

In case of nanoparticles-graphene catalysts, low catalytic activity comes mainly from aggregation. Pure graphene has fewer active sites and makes the nanoparticles (NPs) deposition difficult, so doping can improve both the electrocatalytic performance of graphene support and more uniform dispersion of metal NPs [8,9]. For the durability [10], fuel cell industry has a set of standards [11]; 40000 and 8000 h for lifetime and uninterrupted service, respectively.

\section{5. $\quad$ Tolerance test}

$\mathrm{CO}$ is a common impurity in $\mathrm{H}_{2}$ gas produced by the reforming of natural gas. Pt catalysts have been the best option for the anode and the cathode, but even trace amount of CO can poison the Pt electrodes upon adsorption. CO molecules block the active sites of Pt catalysts to decrease the activity significantly. Hence, CO-tolerance has been a challenging issue in the development of more efficient fuel cell.

The electrolyte should only allow the transport of ions, but some fuel permeates across the electrolyte membrane from the anode to the cathode. This fuel loss leads to a current loss. The fuel crossed over produces an anodic current density and causes a depression of the cathode potential. Fuel crossover can be measured by linear sweep voltammetry or chronocoulometry. Linear sweep potential is similar to the cyclic voltametry, but irreversible scan. The scan potential range is from 0 to $0.8 \mathrm{~V}$. A certain potential is applied to the cathode side of the cell as the working electrode. By measuring the amount of charge by oxidation, the fuel crossover rate can be calculated as current. This fuel crossover results in additional fuel consumption and reduction of cell voltage. Methanol crossover often occurs in direct methanol fuel cells (DMFCs). ORR competes with methanol oxidation on the cathode, if methanol in the anode side diffuses through the membrane to cathode. Low concentration may be a solution, but the maximum current would be limited. This methanol crossover is the main factor in inefficiency to be solved.

\section{Graphene nanocatalysts}

\subsection{Pt}

Pt is one of the best and most commonly used electrocatalysts [12]. However, its high cost is one of the main obstacles to the commercialization of fuel cells. To resolve this problem, $\mathrm{Pt}$ and Pt alloy nanocatalysts have been supported on graphene derivatives such as graphene nanoplatelets and nanoscale graphite [13]. The Pt supporting strategy has gained much attention because of reducing the high cost of precious metals and increasing the durability of the Pt nanocatalysts. In particular, functionalized graphene-supported Pt NPs have shown the enhanced oxygen reduction activity, better performance in PEM fuel cells, and also higher activity for methanol oxidation reaction (MOR) due to the increased electrochemically active surface area and less aggregation of the NPs. In addition, the vacant sites in the graphene can serve as anchoring points for the growth of the nanocatalysts. Mu et al. [14] demonstrated that both electrochemical activity and stability of the reduced graphene oxide (RGO) supported Pt nanocatalysts could be greatly improved by preserving a proper amount of oxygenated groups on the RGO surface. Accordingly, various strategies have been developed to synthesize Pt nanocrystals with different morphologies. Wang and colleagues introduced a facile approach to efficiently produce well-dispersed Pt-nanoflowers on the surface of polydopamine modified RGO [15]. The synthesis is simply performed by a heating treatment of an aqueous solution that contains $\mathrm{K}_{2} \mathrm{PtCl}_{4}$ and polydopamine modified graphene oxide (GO) without the need for any additional reducing agent or surfactant. Fig. 1(a) and (b) show the morphology and size of the Pt nanoflowers on RGO at different magnifications. The size of the Pt-nanoflowers narrowly ranged from 26 to 34 $\mathrm{nm}$ with an average size of $31 \mathrm{~nm}$ (Fig. 1(c)). The selected-area electron diffraction (SAED) pattern (Fig. 1(a), inset) indicated the face-centered cubic (fcc) Pt crystal structure, which was indexed as (111), (200), (220), and (311) lattice planes of Pt. This result was verified by the X-ray diffraction (XRD) pattern recorded for Pt nanocatalysts (Fig. 1(d)).

The prepared hybrid catalysts exhibited superior electrocatalytic activity and stability for MOR and ORR in alkaline solutions. The electrocatalytic performances in MOR and ORR were compared with Pt-nanodendrites/RGO, Pt-nanostars/ RGO, and commercial Pt/C catalyst. Fig. 2(a) shows the typical cyclic voltammograms of Pt-nanodendrites, Pt-nanostars, and $\mathrm{Pt} / \mathrm{C}$ catalysts for MOR, which were tested in a degassed aque-
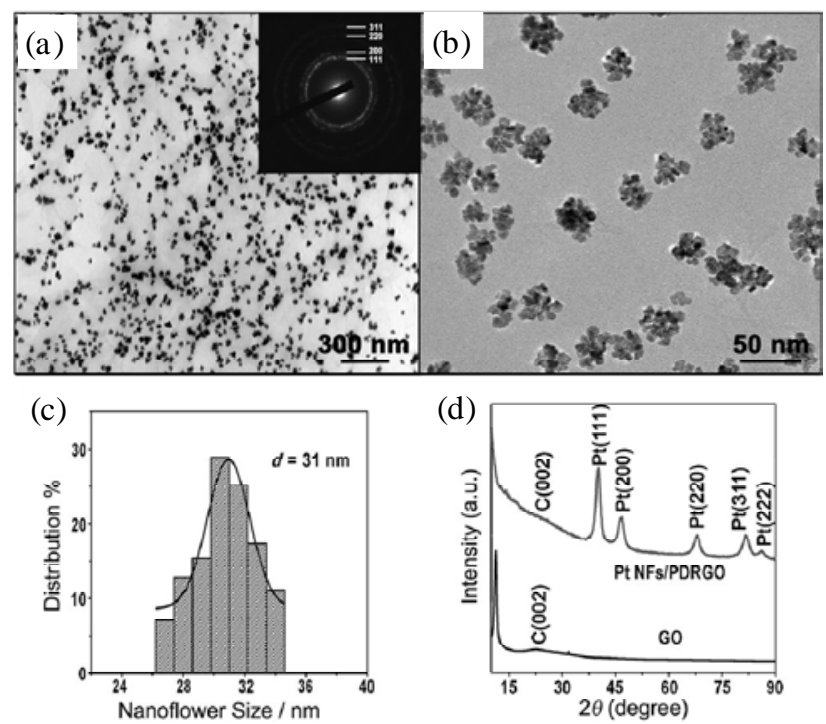

Fig. 1. (a, b) Representative TEM images of Pt nanoflowers on RGO at different magnifications. (c) Size distribution histogram of Pt NPs. (d) XRD pattern of the hybrid catalyst. The inset of (a) displays the corresponding SAED pattern. Reproduced with permission from Ref. [15]. 

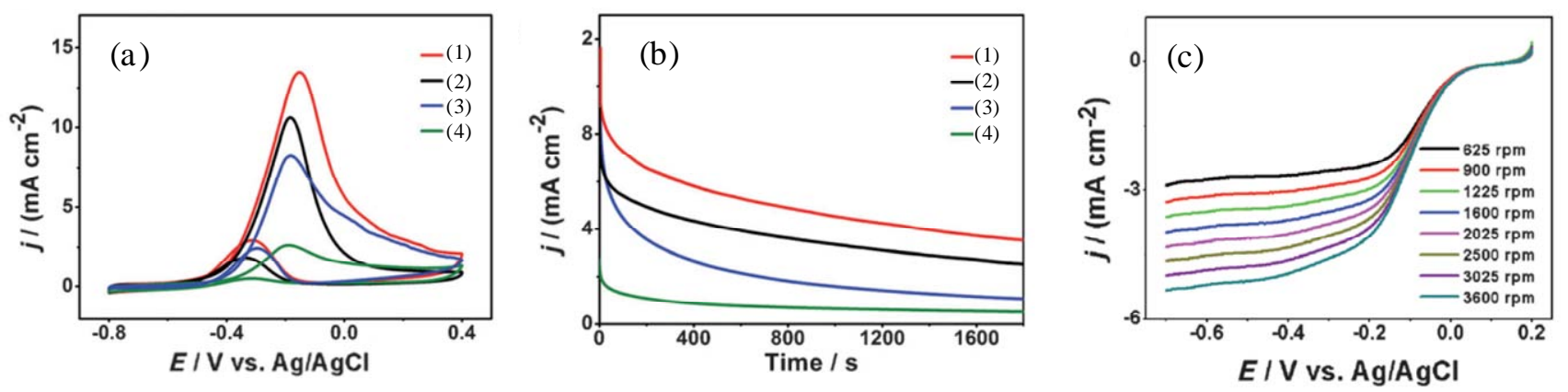

Fig. 2. Cyclic voltammograms (a) and chronoamperometric curves (b) of MOR catalyzed by Pt nanoflowers (1), commercial Pt/C (2), Pt nanodendrites (3) and Pt nanostars catalysts (4) in degassed aqueous $0.5 \mathrm{~mol} / \mathrm{L} \mathrm{NaOH}$ that contained $1 \mathrm{~mol} / \mathrm{L}$ methanol. (c) ORR polarization curves of Pt nanoflowers at different rotation rates. The chronoamperometric curves recorded at $-0.2 \mathrm{~V}$. Reproduced with permission from Ref. [15].

ous solution of $0.5 \mathrm{~mol} / \mathrm{L} \mathrm{NaOH}$ containing $1 \mathrm{~mol} / \mathrm{L}$ methanol. Interestingly, the catalytic peak current density of the Pt-nanoflowers on RGO in the positive direction sweep was higher than those of the Pt-nanostars, the Pt-nanodendrites and the $\mathrm{Pt} / \mathrm{C}$ catalyst. Chronoamperometry curves were recorded as a universal method for evaluating the electrocatalyst stability to conduct the stability of the synthesized catalysts (Fig. 2(b)). Fig. 2(c) shows the polarization curves of Pt-nanoflowers on the RGO recorded at different rotation speeds with a scan rate of $10 \mathrm{mV} / \mathrm{s}$. These results confirmed the superior electrocatalytic activity and stability of Pt-nanoflowers on the RGO for the MOR and ORR in alkaline solutions.

\section{2. $P d$}

One of the challenging areas in the fuel cell developments is to find non-Pt catalysts for ORR that allow high efficiency and durability. Accordingly, a wide range of alternative catalysts is reported to replace Pt [16]. Among them, Pd has a similar valence shell electronic configuration and lattice constant to $\mathrm{Pt}$ [17]. Pd is considered as a promising candidate because of not only lower cost and more abundance than Pt but also more electrochemical stability in acidic and alkaline electrolytes compared with other catalytic metals. However, there are several drawbacks limiting the use of Pd electrocatalysts in fuel cells such as their scarce electrochemical stability at high potentials. The common strategy for increasing the activity and stability of Pd NPs is to disperse them on supports having high electrical conductivity, large specific surface area and sufficient mechanical stability. In this regard, the high surface area (theoretical value of $2630 \mathrm{~m}^{2} / \mathrm{g}$ ), the high conductivity, and the potentially low-cost manufacturing make RGO an optimal candidate for this purpose. Recently, Yu et al. [18] found that the RGO supported Pd NPs with size of $\sim 3 \mathrm{~nm}$ presented very high catalytic activity comparable with $\mathrm{Pt} / \mathrm{C}$ catalysts, maintaining its high performance after 4000 cycles of potential sweep. Janowska et al. [19] reported the few-layered graphene-supported Pd nanocatalysts (Pd/FLG) with outstanding performance in alkaline solutions.

The FLG was first prepared according to a previously published procedure by an easily-scalable, eco-friendly and low-cost method consisting of the ultrasonic-assisted mechanical exfoliation of pencil lead [20]. The transmission electron microscopy (TEM) micrograph (Fig. 3(a)) showed a relatively high dispersion of Pd on the FLG surface. The sharp XRD peaks at $27^{\circ}$ and $55{ }^{\circ} \mathrm{C}$ confirmed the presence of the highly graphitized FLG support (Fig. 3(b)). Atomic force microscopy (AFM) characterizations demonstrated the existence of well-separated elongated structures with intermittently connected forming island-like structures (Fig. 3(c) and (d)). The ORR investigations of the Pd/FLG showed superior performances compared to $\mathrm{Pt} / \mathrm{C}$ and $\mathrm{Pd} / \mathrm{C}$ references in a long-term experiment (Fig. 4). The Pd/FLG exhibited the highest ORR performance among the monometallic family of catalysts in alkaline media.

\section{3. $\mathrm{Au}$}

Traditionally, bulk Au has been considered as a stable and chemically inert precious metal, and rarely used as a catalytic material. However, Haruta et al. [21,22] challenged that view couples of decades ago and they fortunately elucidated that $\mathrm{Au}$ can have exceptional reactivity when it is dispersed as nanoscale particles. So far, tremendous works about Au catalysis have been published since catalytic promotion effects of Au NPs on a variety of reactions such as reduction, and oxidation were reported [23-25].
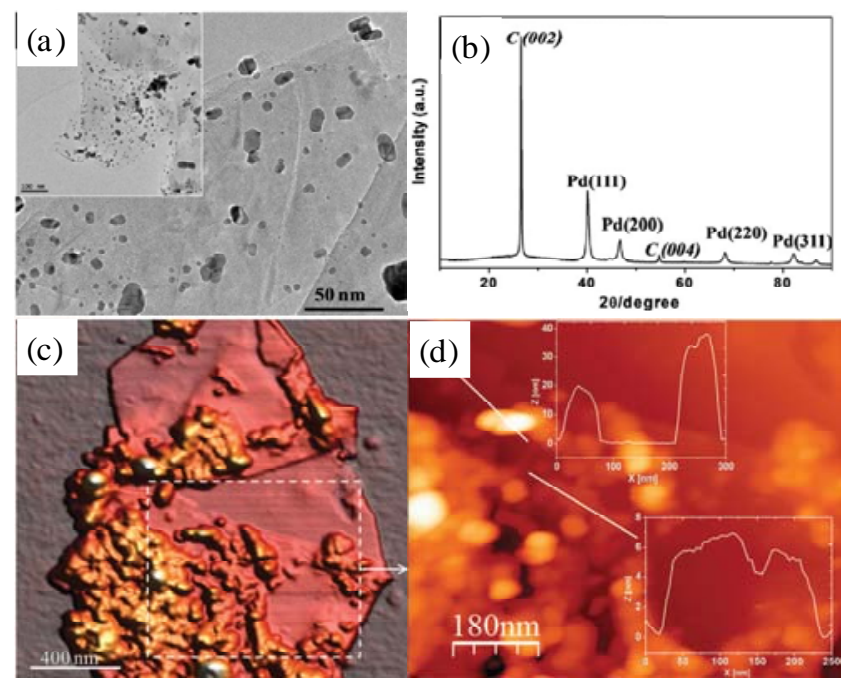

Fig. 3. (a) TEM image of the Pd/FLG catalyst. (b) Powder XRD pattern of the Pd/FLG catalyst. AFM image (c) and profile mapping (d) of the Pd/FLG catalyst. Reproduced with permission from Ref. [19]. 

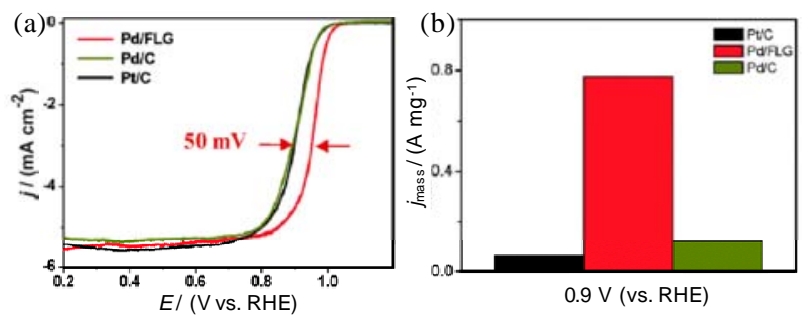

Fig. 4. Polarization curves (a) and mass-normalized current densities (b at $1600 \mathrm{r} / \mathrm{min}$ of Pd/FLG catalyst compared to Pt/C and Pd/C references. Reproduced with permission from Ref. [19].

Since it is well known that graphene and its derivates showed synergetic effects in many chemical reactions, especially electrocatalysis [26-30], when used as catalytic materials, new class of Au-graphene hybrid catalysts were suggested and investigated for practical catalytic applications during past decades [31-33]. With continuous development in synthetic methodology for controlling nanomaterials and manipulation of surface chemistry on graphene, well defined $\mathrm{Au} /$ graphene hybrid catalysts were fabricated through various synthetic strategies [28,34-37]. It could be thought that one can directly use anchoring strategy to fix Au NPs on the graphene surface through making $\mathrm{Au}-\mathrm{S}$ bonds using sulfur-functionalized GO. Recently, Xia et al. [34] demonstrated Au-graphene hybrids through ex-situ synthesis using sulfhydryl-functionalized GO and pre-synthesized $\mathrm{Au}$ NPs. To functionalize the surface of graphene, they used excessive 2-amonioethanethiol hydrochloride as a glue chemical, and synthesized $\mathrm{Au}$ particles by $\mathrm{NaBH}_{4}$ reduction method. They induced self-assembly of Au NPs on sulfhydryl-functionalized surface of GO to form uniformly dispersed $\mathrm{Au} /$ graphene catalyst. Instead of 2-amonioethanethiol hydrochloride, some biomaterials such as DNA can also be used as glue materials to form interaction between Au and graphene [38,39].

In recent publications, $\mathrm{Xu}$ et al. [36] reported synthesis of Au-nanodendrites on GO nanosheets by using a simple and clean synthetic approach. They first dispersed GO nanosheets in water with aid of ultrasonication and mixed an Au precursor. The above GO suspension containing Au precursor was kept under vigorous ultrasonication and $\mathrm{Au}$ ions can eventually be reduced to Au cluster, grown to particles, and finally proceeded to become the nanodendrite. Fig. 5(a)-(c) revealed the formation of dendritic Au nanostructure, demonstrating the high yield of the Au-nanodendrites on the surface of GO nanosheets. The size of the uniform and monodisperse Au nanodendrites was in a range from 25 to $35 \mathrm{~nm}$ with an average size of ca. 29 nm (Fig. 5(d)). As shown in Fig. 5(e), The high resolution TEM (HRTEM) image indicates that each NP is a dendritic entity with branches in various directions. The selected area electron diffraction (SAED) pattern of Au nanodendrites on GO indicates an fcc Au crystal structure and interplanar spacing $(d)$ of the lattice fringes is ca. $2.36 \AA$, corresponding to (111) planes (Fig. 5(f)). They reported that the formation of Au-nanodendrites on GO can be mainly attributed to direct redox reaction between $\mathrm{GO}$ and $[\mathrm{AuCl}]^{4-}$ ions and three dimensional dendrite structures can be controlled by diffusion limited aggregation mechanism
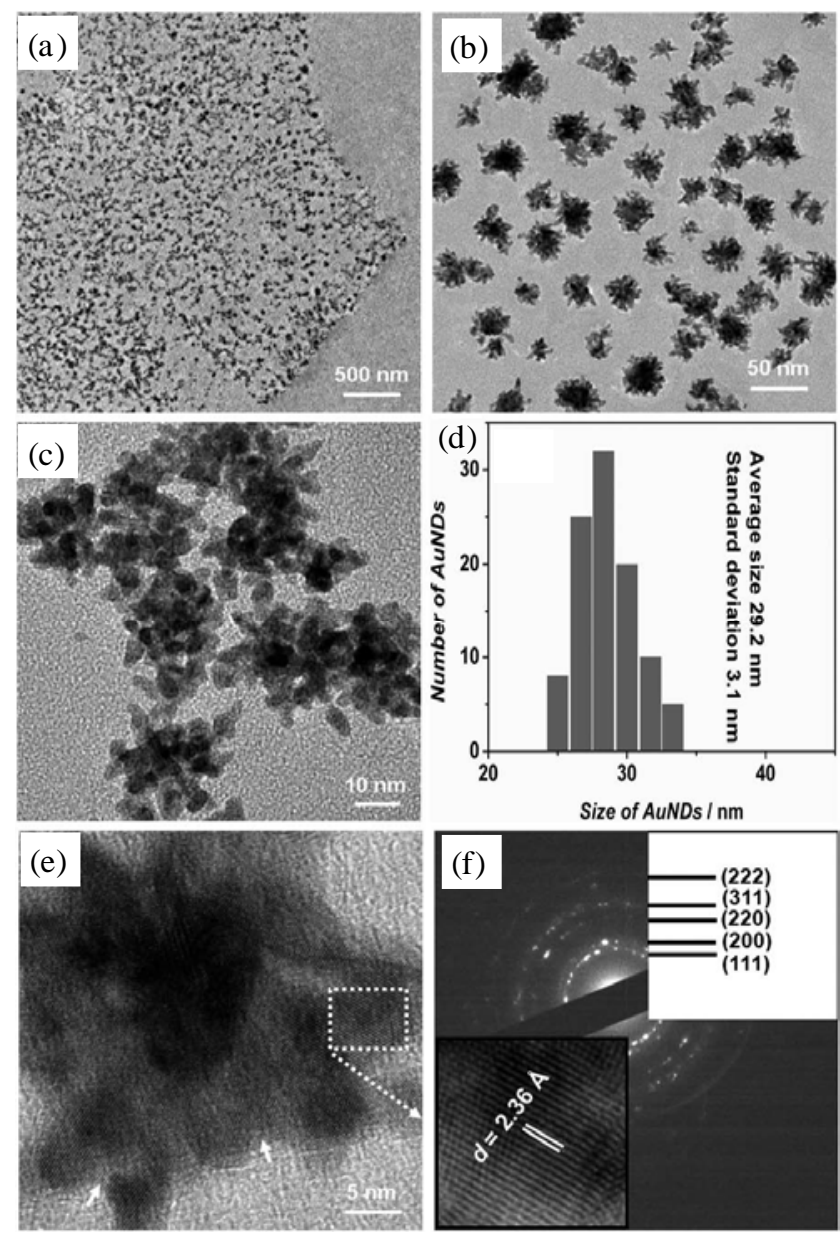

Fig. 5. Typical TEM images (a-c), particle size distribution results (d), HRTEM image (e), and SAED pattern (f) of the as-prepared $\mathrm{Au}$-dendrites/GO. Reproduced with permission from Ref. [36].

under appropriate reaction conditions with kinetic control $[36,40]$. Final Au/GO catalyst has advantageous characteristics such as surfactant-free surface of Au-nanodedrites and excellent monodispersity without any Au sintering, and exhibits high electrocatalytic activity toward oxygen electro-reductions. Though Pt/C is the most active catalyst for ORR, the prepared Au-nanodedrites/GO catalyst shows excellent durability and methanol tolerance with similar activity compared with Pt catalysts. Gao et al. [41] also reported similar concept for synthesizing surfactant-free Au-clusters/graphene hybrids catalysts for oxygen electro-reduction. They also prepared GO nanosheet and reduced it to RGO by using a reducing agent such as hydrazine with aqueous ammonia. The dried RGO was well dispersed in $\mathrm{Au}$ precursor solutions and $\mathrm{Au}$ ions were spontaneously reduced into $\mathrm{Au}$ cluster under ultrasonic conditions to form $\mathrm{Au}$ clusters on RGO surface. When Au ions are added to the solution containing RGO nanosheets, they exhibit high absorption capacity toward positive-charged Au(III) ions via partial replacement of $\mathrm{Cl}$ ion ligands $[42,43]$. Most $\mathrm{Au}(\mathrm{III})$ ions can then coordinate with the heteroatoms at the defects on the RGO sheets, which act as the initial nucleation site for Au clusters [41]. RGO nanosheets play a role as electron donors or a reducing agent with moderate reduction strength for subsequent 
$\mathrm{Au}$ cluster growth on the RGO surface, in which it is a similar result explored previously that carbon nanotubes could reduce $[\mathrm{AuCl}]^{4-}$ to generate $\mathrm{Au}$ NPs without any reducing agent [44]. The strong absorption and the moderate reduction of RGO sheets toward $\mathrm{Au}$ ions leads to restraining the growth of $\mathrm{Au}$ clusters at the initial nucleation sites resulting in a monodispersed Au-clusters/RGO hybrid catalyst.

Sohn et al. [37] recently reported an interesting approach to synthesize Au/graphene catalysts. They first coated the surface of RGO film with a single layer of diblock copolymer (PS-P4VP, polystyrene-poly(4-vinyl pyridine)) micelles in a non-polar solvent (toluene) with $\mathrm{Au}$ precursor $\left(\mathrm{HAuCl}_{4}\right)$. Since polystyrene portion can be selectively dissolved in the toluene while hydrophilic poly(4-vinyl pyridine) cannot, it forms core-corona typed micelles in the solution. The Au precursor can be existed in the core part and subsequently reduced to Au NPs along with removal of copolymer by heat treatment at $400{ }^{\circ} \mathrm{C}$ under air condition. The diblock copolymer micelles can form well-defined single layer without any overlapping and array of $\mathrm{Au}$ NPs on the RGO surface was obtained with controlled spacing and particle density. Fig. 6(a) shows a monolayer array of spherical micelles without overlapping. After removing of copolymers by heat treatment, Au NPs which are originally from the core regions of the micelles are observed with constant particle-particle distances as shown in Fig. 6(b). TEM image confirms that the arrays of Au NPs having average diameter of ca. $11 \mathrm{~nm}$ on the RGO are well maintained during the transferring $\mathrm{Au} / \mathrm{RGO}$ to TEM grids, suggesting that it is possible to transfer Au NPs on RGO to any substrates (Fig. 6(c) and (d)). One of the merits of the diblock copolymer micelle approach is the flexibility on control of the number of density and the size
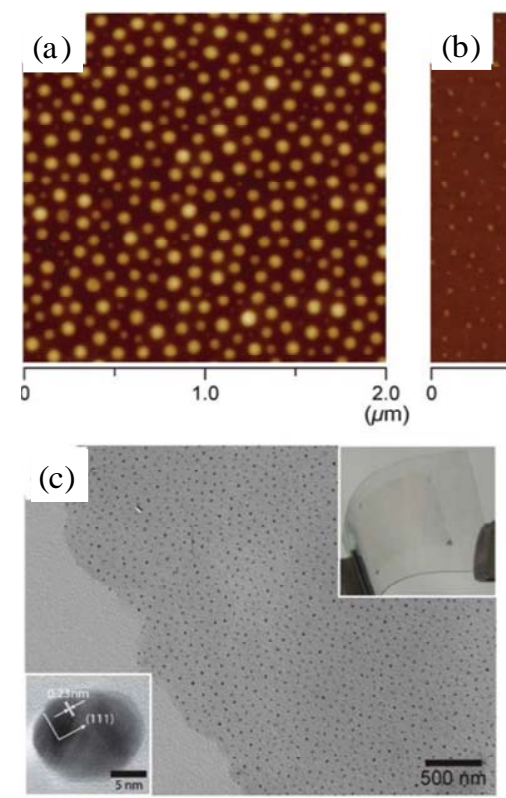

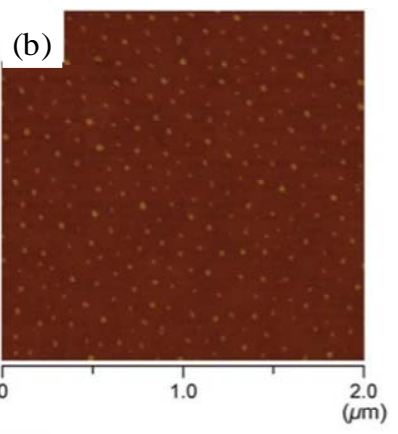

(d)

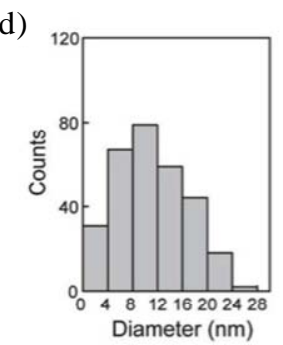

Fig. 6. (a) AFM image of PS-P4VP micelles having molecular weight of $109 \mathrm{k}$ for PS and $27 \mathrm{k}$ for P4VP on RGO. (b) AFM image of Au NPs synthesized from the micelles. (c) TEM image of Au NPs on RGO. (d) The particle diameter distribution of the Au NPs. The insets in (c) are the HRTEM image of an individual Au NPs and the photo of a transferred $\mathrm{Au}-\mathrm{RGO}$ film on a flexible polymer film. Reproduced with permission from Ref. [37]. of $\mathrm{Au}$ particle by adjusting the molecular weight of the block-copolymer employed. Practically, they demonstrated even smaller Au NPs with large number of density without any agglomeration or particle overlapping by choosing a lower molecular weight PS-P4VP [37]. This approach can also be extended to diverse NPs by changing the precursor chemicals for targeted materials during micelle formation. The resulting $\mathrm{Au}$ NPs arrays on RGO support showed different ORR activity and reaction mechanism with the varying size of Au NPs loaded. In the case of $\mathrm{Au}$ (109-27 k) prepared by using PS-P4VP having molecular weight of $109 \mathrm{k}$ for PS and $27 \mathrm{k}$ for P4VP, the average particle size is ca. $11 \mathrm{~nm}$ and The Au (109-27 k) catalyst shows a dominant 2-electron $\mathrm{O}_{2}$ reduction process, that is, reduction of $\mathrm{O}_{2}$ to $\mathrm{H}_{2} \mathrm{O}_{2}$. However, $\mathrm{Au}$ (51-18 k) prepared by using PS-P4VP having molecular weight of $51 \mathrm{k}$ for PS and $18 \mathrm{k}$ for P4VP has ca. $8.6 \mathrm{~nm} \mathrm{Au}$ particle size and 4-electron process, indicating direct reduction of $\mathrm{O}_{2}$ to $\mathrm{H}_{2} \mathrm{O}$, which is desirable for practical applications. It is also confirmed that the electrochemical stability of the Au NPs arrays is well maintained in the ORR conditions such as at constant potential of $-0.6 \mathrm{~V}$ during $2 \mathrm{~h}$.

\section{4. $\mathrm{Ag}$}

In electrochemical catalysis point of views, Ag is also an attractive material because it is not only inexpensive, thermodynamically and/or electrochemically stable at high $\mathrm{pH}$ but also has a moderately high catalytic activity, especially towards ORR in aqueous media [45-48]. Despite their significance on many catalytic and electrochemical applications, it has been difficult to synthesis small well-dispersed Ag NPs without aid of stabilizers or surfactants because small Ag particles tend to agglomerate to reduce the surface energy. Since the stabilizer or surfactant could greatly limit the access of reactant molecules to the active site, it must be removed and catalytically active surface must be exposed. Similar to Au/graphene, novel $\mathrm{Ag} /$ graphene catalysts which have high metal dispersion with clean surface were suggested through a variety of synthetic approaches and investigated as catalysts in electrochemical oxygen reduction.

Munichandraiah et al. [48] reported that Ag NPs-anchored RGO (Ag-RGO) is prepared by simultaneous reduction of GO and $\mathrm{Ag}^{+}$ions in an aqueous medium by ethylene glycol as the reducing agent. They first synthesized GO and well mixed the GO with aqueous Ag precursor solution. After making the solution base conditions by adding small amount of diluted $\mathrm{KOH}$ solution, ethylene glycol was added as the reducing agent and the solution was maintained at $80{ }^{\circ} \mathrm{C}$ to reduce $\mathrm{Ag}^{+}$ions to $\mathrm{Ag}$ NPs as well as GO to RGO simultaneously. The TEM results (Fig. 7(a) and (b)) reveal the presence of layers of RGO and uniformly distributed Ag particles. As shown in Fig. 7(c), particles size is an average size of $4.7 \mathrm{~nm}$. It should be noted that Ag NPs are uniformly anchored over the sheets of RGO, instead of existing as separate phases indicating that all of Ag ions are adsorbed on the surface of GO sheets. Subsequent to the addition of ethylene glycol, GO, as well as the adsorbed $\mathrm{Ag}^{+}$ions undergo simultaneous reduction; thus, producing polycrystalline Ag 

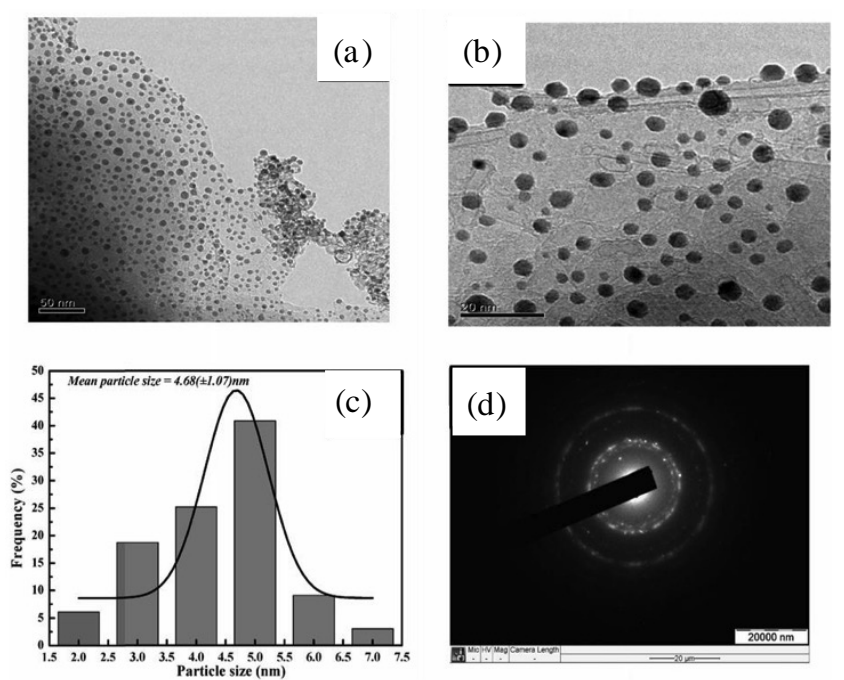

Fig. 7. (a, b) TEM images of Ag-RGO in different magnifications. Particle size distribution (c) and diffraction pattern (d) of Ag-RGO. Reproduced with permission from Refs. [8,48].

anchored RGO layers confirmed from electron diffraction pattern (Fig. 7(d)). The Ag-RGO catalyst showed significantly high catalytic ORR activity in both aqueous and non-aqueous electrolytes.

Kim et al. [49] also reported a similar synthetic strategy, which is simultaneous reduction of Ag and GO without surfactant at ambient temperatures. They also synthesized GO and achieved reduction of the $\mathrm{Ag}^{+}$ions and $\mathrm{GO}$ at room temperature by adding $\mathrm{NaBH}_{4}$ solution. The prepared Ag/RGO catalyst can have surfactant-free Ag surface and show good metal dispersion with small particle size (less than $10 \mathrm{~nm}$ ) even though $\mathrm{Ag}$ loading is up to $60 \mathrm{wt} \%$. Generally, it is difficult to obtain well-dispersed NPs with a high degree of metal loading on carbon support, because the surface area is usually insufficient to achieve a high metal loading and weak metal-support interactions leading to sintering of the metal $[16,50]$. However, functional groups of GO such as epoxy and hydroxyl groups could provide sufficient number of chemically active sites for $\mathrm{Ag}$ deposition and a high metal loading with highly dispersed Ag NPs catalysts can be achieved without the need for surfactants $[43,51,52]$.

Zhang et al. [8] recently reported Ag nanoclusters controllably reduced on $\mathrm{N}$-doped graphene (NG) through electrochemical reduction using effective single-stranded oligonucleotide sequences (ssDNA) and the resulting $\mathrm{Ag} / \mathrm{NG}$ composites were successfully used as ORR catalysts (Fig. 8). Strong interaction formed between ssDNA and graphene surface can lead metal to be absorbed on the GO surface. The ssDNA plays an important role as an intermediate linkage for anchoring $\mathrm{Ag}$ ions and a template for growing Ag nanoclusters, respectively. The resulting $\mathrm{Ag} / \mathrm{NG}$ shows well dispersed Ag nanoclusters with an average diameter of $1.8 \mathrm{~nm}$ on GO sheets, and the size and/or the morphology of $\mathrm{Ag}$ nanoclusters can be controlled by changing the ssDNA templates indicating that controllably assembled Ag nanoclusters on graphene sheets could be obtained via rational designing the ssDNA templates. The resulting

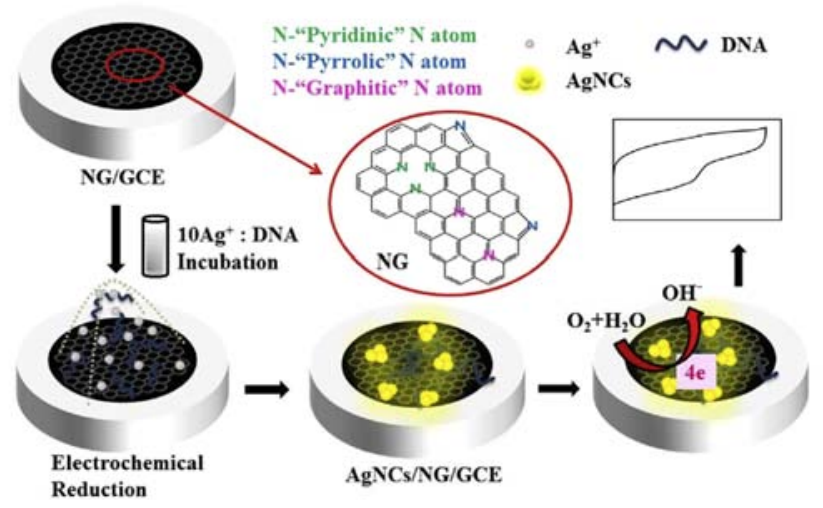

Fig. 8. Schematic illustration of fabrication process of the Ag-nanoclusters/NG composite for ORR catalysis through electrochemical reduction using single-stranded oligonucleotide sequences (ssDNA). Reproduced with permission from Ref. [8].

$\mathrm{Ag} / \mathrm{NG}$ composite exhibits competitive onset potential and mass activity for ORR, compared to conventional Pt/C catalyst. In stability issue, $\mathrm{Ag} / \mathrm{NG}$ catalyst exhibits higher methanol tolerance and excellent durable stability with negligible activity decreases during 8000 cycles of ORR, compared to Pt/C in alkaline electrolyte. The enhanced stability should be resulted from the strong interaction between Ag nanoclusters, ssDNA sequence and NG, in which the Ag nanoclusters are stabilized by coordination with the purine moieties in the ssDNA as well as graphene. The above results prove that $\mathrm{Ag} / \mathrm{NG}$ catalyst owns higher tolerance and superior stability for ORR than commercial Pt/C, which is essential for practical applications in the direct methanol alkaline fuel cells.

\section{5. $\mathrm{Fe}$}

Since 1964 [52], metal phthalocyanines have been used as catalysts for many reactions including fuel cells. Phthalocyanines are chemically stable and insoluble in water and alkali, and the transition metals in $\mathrm{N}_{4}$-chelate complexes reduce electrochemically oxygen as illustrated in Fig. 9(a) [53]. As a fuel cell catalyst, iron phthalocyanines (Fe-Pc) can be alternative to replace Pt-based catalysts if they overcome the issues related to aggregation and poor conductivity. Also, it could be attached homogeneously onto the graphene sheets through $\pi-\pi$ interaction to prevent aggregation during the catalytic reactions [53]. Its conjugated $\pi$-electron system facilitates the interaction and enhances the electrochemical activity of iron phthalocyanine, besides high surface area for an ideal support. Fig. 9(b) and (c) show the cyclic voltammetry curves of ORR on Fe-Pc/graphene and $\mathrm{Pt} / \mathrm{C}$ electrodes in $\mathrm{N}_{2}$ - and $\mathrm{O}_{2}$-saturated $0.1 \mathrm{~mol} / \mathrm{L} \mathrm{KOH}$. $\mathrm{Fe}-\mathrm{Pc} /$ graphene showed a more positive cathodic ORR peak at $0.90 \mathrm{~V}$ and a larger current density than those of commercial 20 wt $\% \mathrm{Pt} / \mathrm{C}$, as well as Fe-Pc and graphene electrodes. The synergistic enhancement was explained by the strong interaction between Fe-Pc and graphene. When Fe-Pc is polymerized (Fe-polyPc) on hydrophilic graphene nanosheets, the $\pi-\pi$ interaction became stronger as indicated by the bathochromic shift of Q band at 669 to $742 \mathrm{~nm}$. As sheen Fe-polyPc/graphene 
(a)

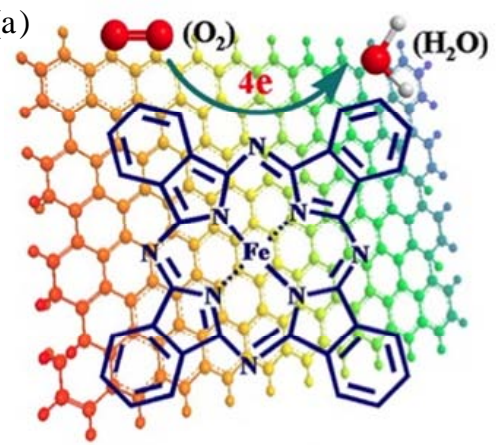

(b)

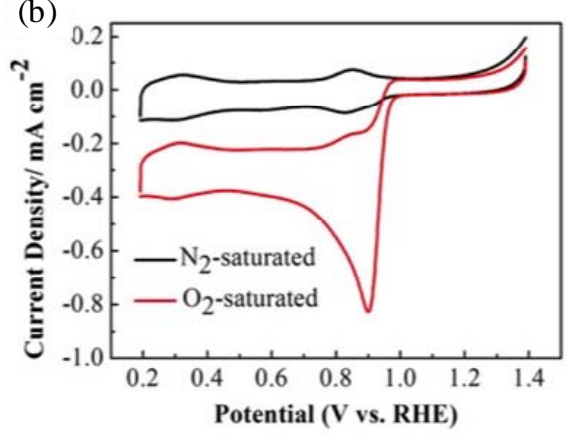

(c)

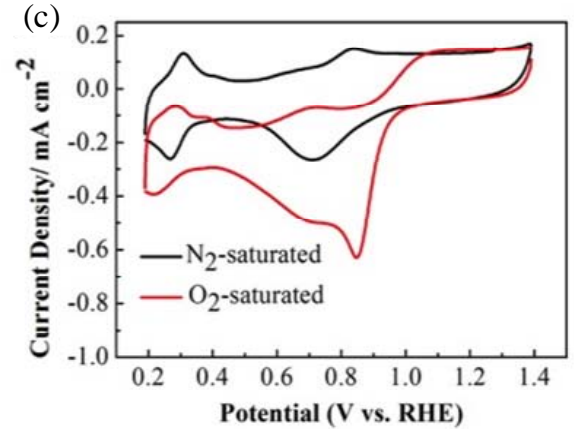

Fig. 9. Schematic illustration (a) of graphene supported iron-phthalocyanine (Fe-Pc/graphene) for ORR, and cyclic voltammetry curves of ORR on the $\mathrm{Fe}-\mathrm{Pc} /$ graphene (b) and Pt/C (c) electrodes in $\mathrm{N}_{2}$ - and $\mathrm{O}_{2}$-saturated $0.1 \mathrm{~mol} / \mathrm{L} \mathrm{KOH}$. Reproduced with permission from Ref. [53].

catalyst showed similar cathodic ORR peak and current density as those of Pt/C. In addition, much better stability and tolerance for methanol crossover. Alternatively, Fe-Pc could be tethered on graphene sheets by amidation reaction between carboxyl functionalized GO and iron tetra-aminophthalocyanine, followed by reduction. Even though the catalytic current density on Fe-Pc-graphene was slightly less than Pt/C electrode, the onset potential for ORR was better as $-0.018 \mathrm{~V}$ on Fe-Pc-graphene electrode than $-0.0075 \mathrm{~V}$ on commercial Pt/C in linear sweep voltammograms.

\subsection{Co}

Nitrogen doping enhances the durability and activity of graphene catalysts for ORR, as the stronger basicity facilitates both $\mathrm{O}_{2}$ adsorption and peroxide decomposition that consequently increase the electrocatalytic activity [9]. Active sites are positive carbon atoms around the doped nitrogen atoms, as more electronegative nitrogen withdraws the electrons from adjacent carbons. Fig. 10 shows a typical $\mathrm{N} 1 s$ spectrum of X-ray photoelectron spectroscopy (XPS) deconvoluted into three components; pyridinic $\mathrm{N}$, quaternary $\mathrm{N}$, and pyridinic oxidized $\mathrm{N}$, those are formed in NG. Higher ORR activity is achievable for

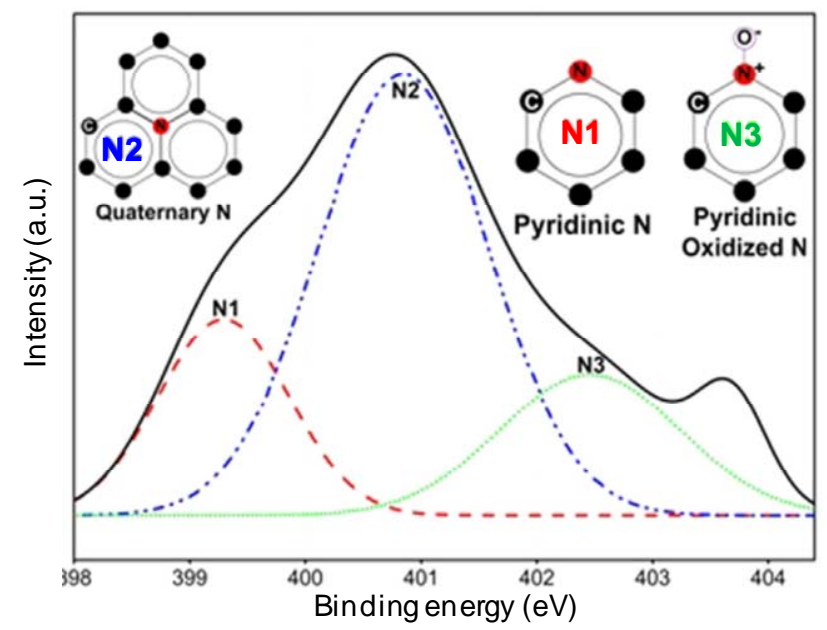

Fig. 10. N $1 s$ XPS spectrum of NG, deconvoluted into three components; quarternary N, pyridinic N, and pyridinic oxidized N. Reproduced with permission from Ref. [9]. catalysts with higher amounts of quaternary $\mathrm{N}$, which is a type of nitrogen bonds to three carbon atoms. $\mathrm{O}_{2}$ molecules preferentially adsorb at the carbon sites. Pyridinic $\mathrm{N}$ creates more edge planes and structural defects at which oxygen-containing species are produced after reaction with oxygen, and also contributes the valence band structure, and its lone pair of electrons facilitates reductive oxygen adsorption.

The exact nature of the active sites is still unknown. However, it is true that transition metals can facilitate $\mathrm{N}$ doping and ORR activity. Among them, Fe and Co have been known to promote the activity. Hence, the optimal dispersion of metal NPs is required for good accessibility of metal sites for oxygen adsorption. Fig. 11 shows the electrocatalytic performance of $\mathrm{Co} / \mathrm{NG}$ and commercial Pt/C [9]. The peak potential of $\mathrm{Co} / \mathrm{NG}$ is enough as $-0.33 \mathrm{~V}$ for ORR, even though $\mathrm{Pt} / \mathrm{C}$ catalyst is better for current density.

\section{Conclusions and outlook}

Graphene-based materials has been hot topics in many research fields including solar cell, fuel cell, battery, supercapacitor, heterogeneous catalysis, etc., and also triggered the recent booming on 2-D materials such as $\mathrm{MoS}_{2}, \mathrm{MoSe}_{2}, \mathrm{WS}_{2}$, or $\mathrm{Bi}_{2} \mathrm{Se}_{3}$. Most of them are related to the energy conversion and storage,

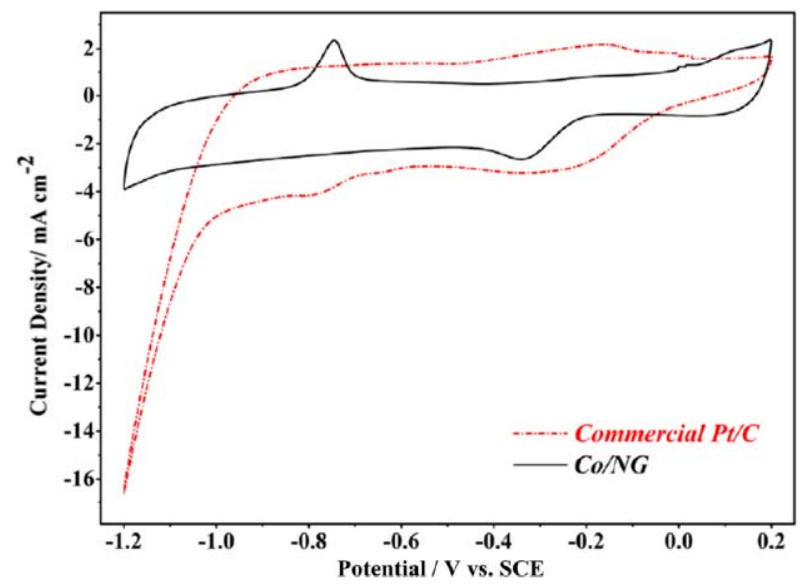

Fig. 11. Cyclic voltammetry of $\mathrm{ORR}$ on $\mathrm{Co} / \mathrm{NG}$ and commercial $\mathrm{Pt} / \mathrm{C}$ electrodes in $\mathrm{O}_{2}$-saturated $0.1 \mathrm{~mol} / \mathrm{L} \mathrm{KOH}$ solution. Reproduced with permission from Ref. [9]. 


\section{Graphical Abstract}

Chin. J. Catal., 2015, 36: 1799-1810 doi: 10.1016/S1872-2067(15)60971-8

\section{Graphene derivatives supported nanocatalysts for oxygen reduction reaction}

Ilkeun Lee*, Ji Bong Joo*, Mohammadreza Shokouhimehr*

University of California, USA;

Institute of Energy Research, Korea;

Seoul National University, Korea

This review presents the recent development of the graphene derivatives supported variable nanocatalysts for oxygen reduction reaction in fuel cells. Discussions describe the major achievements, performances, prospective applications, advantages and challenges of the introduced electrocatalysts.

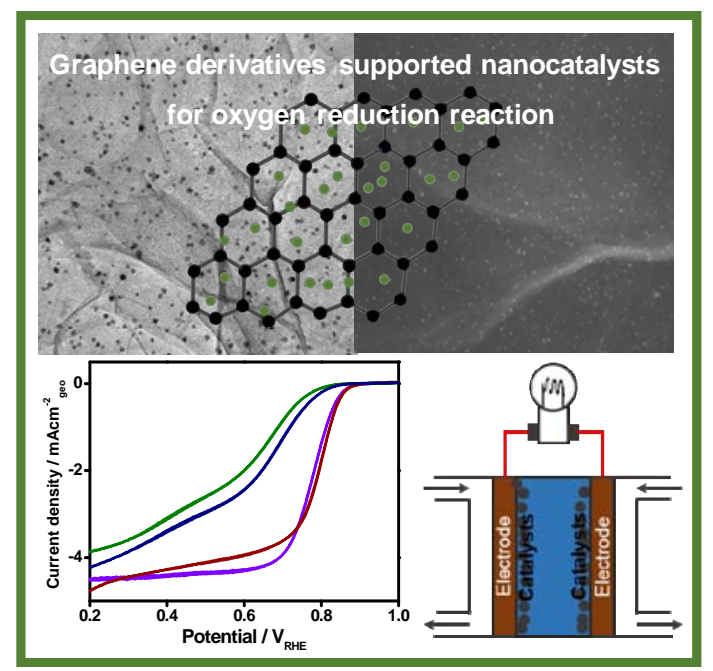

hydrogen production, electrodes, photovoltaic device materials, and catalysts, and their performances in potential applications can be greatly enhanced when controlled in nano-scales. Especially in electrocatalysis of fuel cells, graphene and its derivatives are considered as one of the most promising support materials for ORR. In order to surpass the properties and performances of other electrode materials, however, additional fundamental studies and extensive investigations are still required.

In this review, we have introduced recent efforts on the graphene (or graphene derivatives)-supported nanocatalysts for ORR and discussed catalytic properties and activities. Although we tried to discuss many cases here, the introduced examples are still limited. In addition, there are many challenges left in their practical uses in many electrochemical devices. These may include, for example, curving and/or folding properties which are inherent characteristics of monolayers of graphene and graphene derivate when deposited on the surface of electrodes. It sometimes causes severe decrement of active surface area exposed to the reaction media which hampers achieving the maximum theoretical activity of graphene and/or graphene-derivate nanocatalysts. These drawbacks generally leads to a lower efficiency in the assembled devices. Consequently, to resolve these challenges, some reports introduced a phenomenon and a mechanism on folding issue of monolayer of graphene and/or graphene-derivate which is highly desirable as a general methodology to prevent monolayer folding.

Besides, future research on graphene and/or graphene-derivate nanocatalysts should focus on the optimization of experimental parameters in electrochemical devices to achieve the maximum performances when used as electrode catalysts. Today, most electrochemical devices are optimized based on the conventional electrode catalysts such as Pt/carbon black on cathode in PEM fuel cells. Although gra- phene and/or graphene-derivate catalysts can show higher activities than conventional Pt/carbon black in half-cell test, it might be difficult to achieve the maximum performance of the electrochemical systems because the operating parameters are not well optimized for the investigated graphene and/or graphene-derivate nanocatalysts. Intensive efforts with trial and error on parameters optimization should be obviously considered to resolve the issue.

Another important challenge in the broad application of graphene and/or graphene-derivate catalysts is mass-production with high quality and low-cost. So far, most researches on this area are limited to lab-scale tests on both synthesis and applications [54]. The small amount of the samples with high quality is generally produced for the lab-scale experiments. In order to utilize graphene and/or graphene-derivate catalysts more broadly, they should be produced in large quantity with high quality. Although some chemical approaches (e.g. hummers' method) can provide large amount of the samples, such as gram and/or sub-kilogram, it is hard to guarantee the high quality of the products which hinders their practical applications as efficient cathode catalysts in conventional fuel cells. Because the total cost of graphene production is recently decreasing and the modern techniques for precise properties control of graphene surface is enhancing, it can be expected that the mass-production and high quality issues will be resolved soon.

\section{References}

[1] Zhu C Z, Dong S J. Nanoscale, 2013, 5: 1753

[2] Guo S J, Zhang S, Sun S H. Angew Chem Int Ed, 2013, 52: 8526

[3] Wang Y J, Wilkinson D P, Zhang J J. Chem Rev, 2011, 111: 7625

[4] Song C J, Zhang J J. In: Zhang J Ed. PEM Fuel Cell Electrocatalysts and Catalyst Layers. London: Springer, 2008. 89 
[5] Liu Y, Wu Y Y, Lü G J, Pu T, He X Q, Cui L L. Electrochim Acta, 2013, 112: 269

[6] Liu J F, Takeshi D, Orejon D, Sasaki K, Lyth S M. J Electrochem Soc, 2014, 161: F544

[7] Monteverde Videla A H A, Ban S, Specchia S, Zhang L, Zhang J J. Carbon, 2014, 76: 386

[8] Jin S, Chen M, Dong H F, He B Y, Lu H T, Su L, Dai W H, Zhang Q C, Zhang X J.J Power Sources, 2015, 274: 1173

[9] Ghanbarlou H, Rowshanzamir S, Kazeminasab B, Parnian M J. J Power Sources, 2015, 273: 981

[10] Knights S D, Colbow K M, St-Pierre J, Wilkinson D P. J Power Sources, 2004, 127: 127

[11] Yuan X Z, Wang H J. In: Zhang J Ed. PEM Fuel Cell Electrocatalysts and Catalyst Layers. London: Springer, 2008. 1

[12] He D P, Cheng K, Li H G, Peng T, Xu F, Mu S C, Pan M. Langmuir, 2012, 28: 3979

[13] Li Y J, Li Y J, Zhu E B, McLouth T, Chiu C Y, Huang X Q, Huang Y. J Am Chem Soc, 2012, 134: 12326

[14] He D P, Cheng K, Peng T, Sun X L, Pan M, Mu S C. J Mater Chem, 2012, 22: 21298

[15] Yu X Q, Wang H, Guo L P, Wang L. Chem Asian J, 2014, 9: 3221

[16] Seo M H, Choi S M, Kim H J, Kim W B. Electrochem Commun, 2011, 13: 182

[17] Kong X K, Chen Q W, Lun Z Y. ChemPhysChem, 2014, 15: 344

[18] Huang Y X, Xie J F, Zhang X, Xiong L, Yu H Q. ACS Appl Mater Interf, 2014, 6: 15795

[19] Truong-Phuoc L, Pham-Huu C, Da Costa V, Janowska I. Chem Commun, 2014, 50: 14433

[20] Janowska I, Vigneron F, Begin D, Ersen O, Bernhardt P, Romero T, Ledoux M J, Pham-Huu C. Carbon, 2012, 50: 3106

[21] Haruta M, Yamada N, Kobayashi T, Iijima S. J Catal, 1989, 115: 301

[22] Haruta M. Catal Today, 1997, 36: 153

[23] Lee I, Joo J B, Yin Y, Zaera F. Angew Chem Int Ed, 2011, 50: 10208

[24] Wang S N, Zhang M C, Zhang W Q. ACS Catal, 2011, 1: 207

[25] Wu X F, Song H Y, Yoon J M, Yu Y T, Chen Y F. Langmuir, 2009, 25 : 6438

[26] Geim A K, Novoselov K S. Nat Mater, 2007, 6: 183

[27] Allen M J, Tung C V, Kaner B R. Chem Rev, 2010, 110: 132

[28] Xu S J, Wu P Y.J Mater Chem A, 2014, 2: 13682

[29] Lightcap I V, Kosel T H, Kamat P V. Nano Lett, 2010, 10: 577

[30] Wu D Q, Zhang F, Liu P, Feng X L. Chem Eur J, 2011, 17: 10804

[31] Xu S J, Yong L,Wu P Y. ACS Appl Mater Interfaces, 2013, 5: 654

[32] Dhavale V M, Gaikwad S S, Kurungot S. J Mater Chem A, 2014, 2: 1383

[33] Zhang P P, Huang Y, Lu X, Zhang S Y, Li J F, Wei G, Su Z Q. Langmuir, 2014, 30: 8980

[34] Wang F B, Wang J, Shao L, Zhao Y, Xia X H. Electrochem Commun, 2014, 38: 82

[35] Govindhan M, Chen A. J Power Sources, 2015, 274: 928

[36] Li X R, Li X L, Xu M C, Xu J J, Chen H Y. J Mater Chem A, 2014, 2: 1697

[37] Kim S S, Kim Y R, Chung T D, Sohn B H. Adv Funct Mater, 2014, 24: 2764

[38] Liu F, Choi JY, Seo T S. Chem Commun, 2010, 46: 2844

[39] Liu J B, Li Y L, Li Y M, Li J H, Deng Z X. J Mater Chem, 2010, 20: 900

[40] Imura Y, Maezawa A, Morita C, Kawai T. Langmuir, 2012, 28 : 14998

[41] Yin H J, Tang H J, Wang D, Gao Y, Tang Z Y. ACS Nano, 2012, 6: 8288

[42] Ji X H, Song X N, Li J, Bai Y B, Yang W S, Peng X G. J Am Chem Soc, 2007, 129: 13939
[43] Huo Z Y, Tsung C K, Huang W Y, Zhang X F, Yang P D. Nano Lett, 2008, 8: 2041

[44] Choi H C, Shim M, Bangsaruntip S, Dai H J. J Am Chem Soc, 2002, 124: 9058

[45] Yuan L Z, Jiang L H, Liu J, Xia Z X, Wang S L, Sun G Q. Electrochim Acta, 2014, 135: 168

[46] Liu R J, Yu X L, Zhang G J, Zhang S J, Cao H B, Dolbecq A, Mialane P, Keita B, Zhi L J.J Mater Chem A, 2013, 1: 11961

[47] Davis D J, Raji A R O, Lambert T N, Vigil J A, Li L, Nan K, Tour J M. Electroanalysis, 2014, 26: 164

[48] Kumar S, Selvaraj C, Scanlon L G, Munichandraiah N. Phys Chem Chem Phys, 2014, 16: 22830

[49] Lim E J, Choi S M, Seo M H, Kim Y, Lee S, Kim W B. Electrochem Commun, 2013, 28: 100

[50] Genies L, Faure R, Durand R. Electrochim Acta, 1998, 44: 1317

[51] Shin H J, Kim K K, Benayad A, Yoon S M, Park H K, Jung I S, Jin M H, Jeong H K, Kim J M, Choi J Y, Lee Y H. Adv Funct Mater, 2009, 19: 1987

[52] Jasinski R J. Nature, 1964, 201: 1212

[53] Jiang Y Y, Lu Y Z, Lü X Y, Han D X, Zhang Q X, Niu L, Chen W. ACS Catal, 2013, 3: 1263

[54] Zhao X N, Zhang P P, Chen Y T, Su Z Q, Wei G. Nanoscale, 2015, 7: 5080

[55] Tiwari J N, Kemp K C, Nath K, Tiwari R N, Nam H G, Kim K S. ACS Nano, 2013, 7: 9223

[56] Chen H S, Liang Y T, Chen T Y, Tseng Y C, Liu C W, Chung S R, Hsieh C T, Lee C E, Wang K W. Chem Commun, 2014, 50:11165

[57] Tiido K, Alexeyeva N, Couillard M, Bock C, MacDougall B R, Tammeveski K. Electrochim Acta, 2013, 107: 509

[58] Tan Y M, Xu C F, Chen G X, Zheng N F, Xie Q J. Energy Environ Sci, 2012, 5: 6923

[59] Chou C C, Liu C H, Chen B H. Energy, 2014, 70: 231

[60] Tiwari J N, Nath K, Kumar S, Tiwari R N, Kemp C, Le N H, Youn D H, Lee J S, Kim K S. Nat Commun, 2013, 4: 3221

[61] Nam K W, Song J, Oh K H, Choo M J, Park H A, Park J K, Choi J W. J Solid State Electrochem, 2013, 17: 767

[62] Li Y J, Li Y J, Zhu E B, McLouth T, Chiu C Y, Huang X Q, Huang Y. J Am Chem Soc, 2012, 134: 12326

[63] Carrera-Cerritos R, Baglio V, Aricò A S, Ledesma-García J, Sgroi M F, Pullini D, Pruna A J, Mataix D B, Fuentes-Ramírez R, Arriaga L G. Appl Catal B, 2014, 144: 554

[64] Kakaei K, Gharibi H. Energy, 2014, 65: 166

[65] Zhang P D, Zhang X Y, Zhang S Y, Lu X, Li Q, Su Z Q, Wei G. J Mater Chem B, 2013, 1: 6525

[66] Yu D B, Yao J F, Qiu L, Wu Y Z, Li L X, Feng Y, Liu Q, Li D, Wang H T. RSC Adv, 2013, 3: 11552

[67] Yin H, Zhang C Z, Liu F, Hou Y L. Adv Funct Mater, 2014, 24: 2930

[68] Gao X, Wang J F, Ma Z, Ye J S. Electrochim Acta, 2014, 130: 543

[69] He C Y, Zhang J J, Shen P K. J Mater Chem A, 2014, 2: 3231

[70] Lin L, Li M, Jang L Q, Li Y F, Liu D J, He X Q, Cui L L. J Power Sources, 2014, 268: 269

[71] Li M, Bo X J, Zhang Y F, Han C, Guo L P. J Power Sources, 2014, 264 : 114

[72] Lim C S, Ambrosi, A, Sofer Z, Pumera M. Nanoscale, 2014, 6: 7391

[73] Taniguchi T, Tateishi H, Miyamoto S, Hatakeyama K, Ogata C, Funatsu A, Hayami S, Makinose Y, Matsushita N, Koinuma M, Matsumoto Y. Part Part Syst Charact, 2013, 30: 1063

[74] Zheng B, Wang J, Wang F B, Xia X H. J Mater Chem A, 2014, 2: 9079

[75] Jiang Y Y, Lu Y Z, Wang X D, Bao Y, Chen W, Niu L. Nanoscale, 2014, 6: 15066 


\title{
石墨烯衍生物负载的纳米催化剂用于氧还原反应
}

\author{
Ilkeun Lee ${ }^{\text {a,* }}$, Ji Bong Joo ${ }^{\text {b,\# }}$, Mohammadreza Shokouhimehr ${ }^{\text {c,\$ }}$ \\ a 加利福尼亚大学河滨分校化学系, 美国

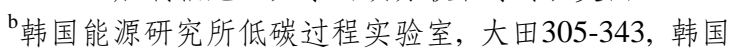 \\ “国立首尔大学工程学院, 化工和生物工程系, 首尔151-741, 韩国
}

摘要: 综述了用于燃料电池中氧还原反应(ORR)的石墨烯衍生物负载的各种纳米催化剂的最新进展. 介绍了用于表征石墨烯基 电催化剂的常规电化学技术以及石墨烯基电催化剂最新的研究进展. 负载于还原氧化石墨烯(RGO)上的Pt催化剂的电化学活性 和稳定性均得到显著提高. 其它贵金属催化剂, 如Pd, Au和Ag也表现出较高的催化活性. 当以RGO或少层石墨烯为载体时, Pd催 化剂的稳定性提高. 讨论了氧化石墨烯负载Au或Ag催化剂的合成方法. 另外, 以 $\mathrm{N}_{4}$ 螯合络合物形式存在的非贵过渡金属可降低 氧的电化学性能. Fe和Co 是可替代的廉价ORR催化剂. 在大多数情况下, 这些催化剂稳定性和耐受性的问题均可得到解决, 但其 整体性能还很难超越Pt/C催化剂.

关键词: 石墨烯; 氧还原反应; 电催化剂; 纳米催化剂

收稿日期: 2015-06-30. 接受日期: 2015-09-09. 出版日期: 2015-11-20.

*通讯联系人. 电子信箱：ilkeun@ucr.edu

\#通讯联系人. 电子信箱: jbjoo@kier.re.kr

通讯联系人. 电子信箱: mrsh2@snu.ac.kr

本文的英文电子版由Elsevier出版社在ScienceDirect上出版(http://www.sciencedirect.com/science/journal/18722067). 